Young Turk Assessments of International Politics, 1906-9

Author(s): Hasan Ünal

Source: Middle Eastern Studies, Vol. 32, No. 2 (Apr., 1996), pp. 30-44

Published by: Taylor \& Francis, Ltd.

Stable URL: https://www.jstor.org/stable/4283792

Accessed: 29-01-2019 06:32 UTC

JSTOR is a not-for-profit service that helps scholars, researchers, and students discover, use, and build upon a wide range of content in a trusted digital archive. We use information technology and tools to increase productivity and facilitate new forms of scholarship. For more information about JSTOR, please contact support@jstor.org.

Your use of the JSTOR archive indicates your acceptance of the Terms \& Conditions of Use, available at https://about.jstor.org/terms

Taylor \& Francis, $L t d$. is collaborating with JSTOR to digitize, preserve and extend access to Middle Eastern Studies 


\title{
Young Turk Assessments of International Politics, 1906-9
}

\author{
HASAN ÜNAL
}

Although scholarly interest has focused on the Young Turks' organizational structure and their internal politics, no attempt has been made to analyse the main components, basic motives and aims that influenced the external policies pursued by the Young Turks during their decade in power from 1908 to 1918. Nor has there been any examination of the foreign policy ideas of the Committee of Union and Progress (hereafter the CUP, the strongest Young Turk organization which dominated Turkish politics between 1908 and 1918, and even thereafter) and its assessments of international politics while in opposition prior to the Young Turk Revolution of 1908.

This dearth of scholarly research can be explained partly by the relative inaccessibility of the Ottoman records which obviously constitute the principal source for the study of these subjects. This may seem a drawback at first sight, but not a fatal one: the archives of the Ottoman Empire began to be sifted through and reorganized in a modern way approximately ten years ago, though substantial sections remain closed pending cataloguing. As a result, large quantities of original documents have been released, which have since enabled a limited number of scholars to produce well-researched studies of aspects of Ottoman foreign policy in the late nineteenth and early twentieth centuries.' It also appears that some scholars seem to have conducted researches into the Ottoman primary sources, and produced studies on the foreign policy of the Empire in the late nineteenth and early twentieth centuries, as well as on the genesis of the Young Turkish organizations even before the process of modernization in the Ottoman archives got underway. ${ }^{2}$

It is, therefore, clear that the relative inaccessibility of the Ottoman archives is part, but only part, of the explanation. A further explanation for the lack of studies on the foreign policy of the Ottoman Empire in its dying years lies in over-simplified a priori assumptions about the Young Turks' anglophile leanings. These preconceived ideas seem to have discouraged archival research to such an extent that almost all the writers on the Young Turk era have focused upon British policy towards the Ottoman Empire, arguing that it was Britain's attitude of indifference tinged with hostility which effectively moulded the foreign policy of the pro-British and anti-German Young Turks. They concluded that it was due to the Britain's cold-shoulder to the Young Turks from 
the outset of the revolution of 1908 onwards that the Ottoman Empire was forced into an undesirable dependence upon Germany and Austria-Hungary, which culminated in the Ottoman intervention in the First World War on the side of the Central Powers. ${ }^{3}$ Regardless of their questionable merits as accounts of British policy towards the Ottoman Empire, ${ }^{4}$ such claims faithfully echo the propaganda put out by the Young Turks themselves, particularly after their final defeat in 1918. Such propaganda was no more than self-justification, and not very informative at that. ${ }^{5}$

The views of the CUP on foreign policy are no exception to the rule of lack of scholarly research. Here again, this is not for want of evidence, but for a priori assumptions about the pro-British and, by implication, pro-French sentiments of the Young Turks. However, the evidence, which is by no means negligible in quantity, seems to suggest that all those over-simplifications are open to challenge.

It appears that following the famous split in the Young Turk movement in $1902{ }^{\circ}$ the group around Ahmed Riza adopted a policy of nationalism as opposed to its previous positivist leanings, and that it transformed itself into a revolutionary organization under the guidance of Dr Bahaeddin Şakir. ${ }^{7}$ It also appears that this group, which was to form the core circle of the CUP in later years after the Young Turk revolution of 1908, indulged itself in foreign policy analysis from the Ottoman point of view in its numerous publications. In particular, Ahmed Riza's Mechveret Supplément Français published much commentary on European politics. The conclusions which may be drawn from perusing these journals are reinforced by surviving CUP correspondence and memoirs. These conclusions are also supported by original documents in various archives which cast light upon the CUP's assessments of European politics, as well as upon Ottoman foreign policy-making in the first year following the Young Turk revolution.

From the perusal of these CUP publications from 1902 onwards, two principal observations may be made. First, the CUP exhibited a marked hostility and suspicion towards all the Great Powers and a strong resentment of their interference in Ottoman affairs. Second, even at this stage before its assumption of power, the CUP manifested no special sympathy, as alleged, towards the Constitutional Powers, Britain and France. On the contrary, anti-British statements outnumber statements against any other Power. It may be assumed that this Anglophobia was in part a reaction to the Anglophile sentiments continuously professed by the rival Young Turk group around Sabahattin Bey, but that said, there seems to be no reason to doubt that the CUP's mistrust of Britain was the product of genuine conviction.

Behind the CUP's mistrust of the European Great Powers, especially of Britain and France, lay a belief in their fundamental hostility towards the Ottoman Empire, and towards the Turks and the Muslims in particular. This 
hostility, the CUP believed, was most clearly manifested in the support which Britain and France allegedly provided for Armenian and Bulgarian revolutionaries, simply because these 'bandits' were attacking an Islamic Power. In one of the barrages of invective directed against the Balkan Committee of London, composed of 'clergymen et politiciens les plus fanatiques', Mechveret Supplément Français declared:

. . . les Musulmans commencent à voir clair dans ces manoeuvres perfides, et ce sont les concurrents des Anglais en Orient qui aident à leur dessiller les yeux. Ils leur disent que, l'Angleterre, agit par haine et par jalousie; elle est mécontente, 'en a assez' du refus systématique qu'oppose le Sultan aux demandes relatives aux affaires de certain sujets britanniques, et elle fait entendre que, lassé de cette persistante hostilité du gouvernement ottoman envers elle, elle saisira dorénavant toute occasion de harceler ses adversaires ... ${ }^{8}$

These and several leading foreign policy articles, if examined on their own, may be seen as mere responses to passing events. However, surviving CUP correspondence leaves no doubt that this commentary was an expression of deep-seated convictions and a deliberate policy adopted by the CUP leadership from 1906 onwards. Nothing can explain this policy better than an episode which occurred at the beginning of 1907 , leading to the resignation from the CUP of pro-British Ali Haydar Bey, the son of the celebrated Midhat Pasha, venerated by the Young Turks as the father of the Constitution of 1876. The Central Committee's explanation of the circumstances of his resignation makes it clear that the CUP was, in fact, endeavouring to publish letters, articles and news of any kind which depicted Britain as the enemy of the Ottoman Empire and the Turks. A long message sent by the CUP Central Committee to Ali Haydar Bey's branch, and circulated to all other CUP organisations puts it bluntly:

... A letter denouncing the malicious anti-Turkish policy of the British government was received by the Sura-yl Ümmet for publication. Discussions took place as to whether or not the letter should be published. In the end, one group favoured the idea of publication, on the grounds that we, the Turks, would regard all the nations who treat us in a friendly manner as friend and look down all those who endeavour to stamp out the Turkish nation of the world as foe, and that we should take it upon ourselves to warn our citizens of the enemy.

They went on to say that they could no longer view the British with benevolence as they had done in the past, in that it was, after all, the British government and particularly the British which had been acting in an extremely anti-Turkish manner and making up calumnies against the 
Turkish nation, and which never cease to use all the means at their disposal to amputate Macedonia from the Empire for Bulgaria, and which yesterday excited and encouraged the Armenians and are now stirring up the Bulgarians and the Arabs against the Turks. The other group, though admitting that British policy has been detrimental to Turkish interests for the last some years, was against the idea of publication, on the grounds that it would not be a good policy to further antagonize the British with such hostile publication. We, therefore, decided to publish the letter as it was; but, for the sake of expediency, we also decided that the Sura-yl Ümmet publish some kind of observation with a view to flattering the British. Ali Haydar Bey, who opposed any kind of antiBritish publication on any account, handed in his resignation, and this was accepted unanimously ... 9

In the same year, the CUP Central Committee in Paris asked Halil Halid Bey, ${ }^{10}$ a Young Turk living in exile in London, to collect anti-Turkish articles and reports from the British press, as well as speeches by MPs in the House of Commons, and to send them all to the Central Committee in Paris. The objective was, as the Central Committee's 'instruction' pointed out, to use these reports to persuade those who still 'look on the British as our friend', that 'the British are our chief enemy'." In order to stimulate anti-British sentiments across the Empire, the CUP also requested one of its members in Larnaca, Cyprus, to write articles for publication in the Sura-yı Ümmet, demonstrating that Britain was no longer pursuing friendly policies as she had done in the past, in particular, in the 1830s and 1840s. On the contrary, she was now inciting the Armenians, the Macedonian revolutionaries and even the Arabs against Turkish rule. ${ }^{12}$

These anti-British tendencies gathered momentum with the Anglo-Russian rapprochement and reached a peak with the signing of the Convention of 1907 between the two Powers. As early as July 1906, the CUP had expressed concern at the Anglo-Russian rapprochement, asking whether 'these two Powers will decide to seal their reconciliation at Turkey's cost', and noting that the Anglo-French understanding of 1904 had resulted in the final loss of Egypt to the Ottoman Empire. ${ }^{13}$ The CUP continued to view the rapprochement with increasing apprehension, criticizing, in particular, the Anglo-Russian scheme for the creation of a mobile force in Macedonia. Indeed, the CUP maintained that the whole chaotic situation in the Ottoman Balkans was of British making, with roots going back to the Bulgarian annexation of Eastern Rumelia in 1885. But for British support and encouragement, Bulgaria would, the CUP declared, never have pressed ahead with the annexation. ${ }^{14}$

Not that the other Powers were any better. Though less frequently vented, the CUP's hostility towards Russia was intense, and mingled with a quasi- 
racial Slavophobia. In a leading article in March 1906, Mechveret Supplément Français urged the whole of Europe to wake up to 'le Péril Slave'. It argued that 'if there is now a danger in the making in Europe, that is le péril jaune ...', is adding, however, that the true 'péril jaune' was not the peoples of East Asia, but the Russians and the Slavs. ${ }^{16}$ In particular, Russia's leading role in the international reform actions in Macedonia earned her repeated condemnation, and it is striking that when, in May 1908, the CUP announced its existence in Macedonia through notes to the Powers' consulates at Monastir, the Russian consul alone was not deemed worthy of a note. ${ }^{17}$

As to the other Powers, their willingness to participate in the Macedonian reforms condemned them all, and their collective naval demonstration of December 1905, with which they forced the Sultan to accept an international financial commission for Macedonia, provoked strong criticism from Ahmed Riza. ${ }^{18}$ In a leading article entitled 'Croisade Navale', published in the Mechveret Supplément Français, he stated that '. . . the armed intervention of the Powers is not at all justified, and the Ottoman government has perfectly the right to observe to them that if it is desired that Turkey continues with the reform works commenced in the three vilayets, it is imperative that its prestige remains unharmed'. The article indirectly accused the Powers of seeking to destroy the authority of the Ottoman state, asking what respect a government could inspire, and what confidence it could be accorded by its subjects, if and when it bowed to 'illégitimes et insultantes sommations' ${ }^{19}$ Ahmed Riza concluded that the naval demonstration could teach the Turks only one lesson: 'to always view with suspicion in a sense of disgust whatever has been proposed by the Powers: do they (the Turkish nation) not know after a series of cruel experiences that they (the Powers) are never interested in the real needs of the Turks or the Ottomans? ${ }^{20}$ When the Sultan gave in in the face of the naval demonstration, the CUP on the one hand lamented the fact that it was all due to the 'couardise du Sultan'. It complained, on the other, that 'the Powers are in the habit of trying to resolve their affairs with Turkey comme les apaches règlent les leurs avec les particuliers dans les ruelles obscures . . . '. It concluded with a threat: not only did the demonstrations fail to produce any results, but 'they are making the Turkish people impatient; they are irritating the Turks, pushing them to revolt ...' '. ${ }^{21}$

One further reflection of the CUP's fundamental anti-Europeanism was its expression of solidarity with other states threatened by European imperialism. In January 1907, for instance, reports of skirmishes between the Ottoman Empire and Persia led Mechveret Supplément Français to declare that it was deplorable that the two countries should have attacked each other. Putting the blame on the Sultan and the Shah, it emphasized that "neither the Shah nor the Sultan has the right to play with our independence and sell to foreigners what belongs to us, and what is our most expensive thing'. The article in the paper 
added that what both countries needed was not only 'an ordinary peace in the passive sense, but also solidarity, fraternity as they have been perceived and prescribed by Islam'.$^{22}$ In a similar fashion, the Șura-yı Ümmet, in an article entitled 'Persian-Turkish Alliance', criticized not only the Shah of Iran but also all the other independent and semi-independent Muslim rulers of Morocco, Tunisia, Egypt and so forth for not reforming and developing their countries. Instead, they were all heavily engrossed, the Sura-yl Ümmet attacked, in satisfying their bestial desires. ${ }^{23}$

But this emphasis on Muslim solidarity was laced with a strong dose of Turkish nationalism. Surviving CUP records for the years 1906-7 show that the CUP Central Committee in Paris took a particular interest in the Muslims of the Russian Empire, most of whom were Turkic, and that it corresponded with sympathizers in the Caucasus, Azerbaijan, Dagestan and even Central Asia. It is also interesting to note that the CUP had branches in Bosnia and Herzegovina, Ottoman provinces occupied since 1878 by Austria-Hungary, and that in 1907 it instructed these branches to work to disseminate the Turkish language among their Muslim compatriots, most of whom spoke a form of Serbo-Croatian as their mother tongue. ${ }^{24}$

However, it appears that the CUP was always at pains to disguise its Turkish nationalist, and by implication, anti-Christian leanings particularly in its Ottoman-Turkish publications. For instance, when it severely criticized the Armenians in the Caucasus for attacking, looting and destroying Muslim villages in the region, it carefully made a distinction between the Armenians living in and outside the Ottoman Empire. According to the Sura-yl Ümmet the Armenians in the Caucasus were entirely different from the Ottoman Armenians in terms of their human sentiments and human structure, indicating that the Ottoman ones were better human beings, and also that they were Ottoman citizens. In an address to the Ottoman people on the rumours that Abdülhamid was ill and his days were numbered, the paper declared that the heir to the throne Mehmed Reșad would be a better Sultan as his sympathies for a constitutional regime were well-known. But the paper made it clear that whatever arrangement was to be arrived at regarding the question of who should take over, it ought to be done in collaboration with the Christian population of the Ottoman Empire. ${ }^{25}$

It has, thus far, been established that the claims that the Young Turks were sincerely pro-British, pro-French, and, by implication, anti-German do not hold water. Close examination of the evidence clearly suggests that the CUP's thinking on the European Great Powers' politics can hardly be said to have amounted to a coherent foreign policy in the sense of a diplomatic, military or commercial strategy. But the evidence does also reveal a determined attitude, characterized by an anti-Europeanism deriving from a belief that the Powers were out to destroy the political independence of the Ottoman Empire, the 
Muslim community and the Turkish nation. ${ }^{26}$ To this extent, the CUP might seem to have something in common with Abdülhamid; indeed, the chief burden of the CUP's criticism of the Sultan's handling of foreign affairs was simply that he was too submissive and complacent in the face of the 'snobbism' of the European Powers. But the resemblance is superficial. Abdülhamid's anti-Europeanism and his fundamental mistrust of all the Powers were rooted in a sense of his own Empire's weakness, and it was, in a way, conservative: he accepted the prevailing international order as given, and sought only to ensure the Empire's survival within it. In contrast, the antiEuropeanism of the CUP was rooted in an aggrieved and assertive nationalism, some of whose implications in international affairs were potentially revolutionary.

The questions of whether and how these assertions of the CUP on European international relations could be translated into a practical foreign policy seem to have been addressed in the period in the immediate aftermath of the Young Turk revolution of 1908. It appears that, though fundamentally hateful of all of them, the first line of policy adopted by the CUP was based on the idea of winning over all the Powers through vague profusions of friendship for each of them, which, the CUP seems to have assumed, would disguise its underlying anti-Europeanism and its lack of any firm diplomatic preferences for one or the other Powers.

For instance, prior to returning to Constantinople from exile, Ahmed Riza set out to cultivate diplomatic contacts in a number of European capitals. Though he had previously criticized Britain consistently in his leader comments in the Mechveret Supplément Français, this time he sought to obtain British friendship. As early as 17 August 1908, he wrote in the name of the 'Comité ottoman d'Union et Progrès' to Sir Edward Grey, British Foreign Secretary, as well as to the King Edward VII, asking to see them, and emphasizing that the Young Turks always remembered 'the assistance of the valiant British troops during the Crimean War and the sublime intervention of the British government in the Turco-Russian war'. ${ }^{27}$ Grey, who was out of London on holiday at the time, instructed the Foreign Office to acknowledge the letter, and to state that he would be willing to see Ahmed Riza at the beginning of October: in the meantime, the Young Turk leader might see Sir Charles Hardinge, Permanent Under-Secretary at the Foreign Office, or else he might communicate his views, should he prefer, through Sir Francis Bertie and Sir Gerald Lowther, British Ambassadors respectively in Paris and Constantinople. Grey added that Ahmed Riza's 'reputation as a Great Liberal Reformer' was 'well known' to him..$^{2 B}$

At the same time, Ahmed Riza was making approaches to other Powers. In Paris, he told Stephen Pichon, French Foreign Minister, that the Young Turks looked to France and Britain, 'the land of liberty, civilisation and consti- 
tutionalist government, for sympathy and help in the task of regenerating the Turkish Empire'. He added, however, that he had been in touch with the German Embassy in Paris, and that he proposed to visit Germany, ${ }^{29}$ for it would be necessary for the Young Turks to stand well with all the Powers ${ }^{30}$ Ahmed Riza visited Berlin at the end of September, and impressed upon Chancellor Bülow the Young Turks' desire to be on the best possible terms with Germany. These remarks apparently impressed the German Chancellor, who, in turn, instructed the German Ambassador at Constantinople, Marschall von Bieberstein, to act as the 'guardian and enlightened friend of the Turkish people and of Islam'.31

In a similar fashion, the CUP leaders inside the Ottoman Empire were also cultivating diplomatic contacts. In addition to their approaches to British officials during the course of the revolutionary movement in Macedonia, ${ }^{32}$ and to popular demonstrations initiated by the CUP in favour of Britain, shortly after the restoration of the constitution of $1876,{ }^{33}$ Enver Bey and Nâzim Bey, two influential members of the inner circle of the CUP, assured the British Consul-General at Salonica, Harry Lamb, that they counted upon British sympathy and support. They alluded to the recent escape of the notorious Izzet Pasha, the Sultan's First Secretary and a well-known Germanophile, on board a British steamer ${ }^{34}$ but explained that they regarded this incident as a deliberate endeavour by lzzet Pasha to drive a wedge between Britain and the Young Turkish regime at Constantinople. ${ }^{35}$ These contacts were pursued at the capital by Mehmed Talat and Bahaeddin Şakir, respectively Directors of Internal and External Affairs of the CUP, who made a positive impression upon Lowther. ${ }^{36}$ On his return to Constantinople, Ahmed Riza also established contacts with Lowther. ${ }^{37}$

In the meantime, the CUP had also been pursuing diplomatic contacts with the Balkan states, though, here too, the contacts were vague in content, and gave no convincing indication of diplomatic preference. The CUP leadership endeavoured to make use of its established contacts with various revolutionary groups in Macedonia, Bulgarian Greek, or others, to further its relations with the Balkan states to which these groups looked for support. The Bulgarian groups, which had been on the point of exhaustion by the outbreak of the Young Turk revolution, were assisted by the CUP in various places, where the Greek armed bands were told to desist from further attacks upon the Bulgarian element. ${ }^{38}$ Fallen Bulgarian band leaders were exalted as 'heroes' by the CUP in various parts of Macedonia. ${ }^{39}$ The CUP's pro-Bulgarian demonstrations soon reached a point where some representatives of the Great Powers at Constantinople thought that an alliance between the Ottoman Empire and Bulgaria was imminent. ${ }^{40}$ In this, however, they proved mistaken. The CUP was anxious not to antagonize the Greek element in Macedonia. It continued the intimate relations which it had built up over the years with the Greek revo- 
lutionary groups ${ }^{41}$ and although certain Greeks do not seem to have been enthusiastic about collaborating with the CUP any further, ${ }^{42}$ the CUP's relations with the Greeks remained satisfactory. ${ }^{43}$

This trend in the CUP's dealings with foreign states continued with no signs of sincere preferences for one or a group of Powers during the course of the Bosnian Annexation Crisis of 1908-9, the first major external problem faced by the Ottoman Empire after the Young Turk revolution. As the previous authors focused on the CUP's backstairs dealings with Britain and, to a lesser extent, with France only, they concluded that the CUP sought to achieve closer relations, or even perhaps an alliance with Britain, and that the Young Turks became disillusioned by the British rejection. ${ }^{44}$ However, evidence in various archives points to the fact that the CUP conducted behind-the-scene negotiations with, and offered alliances to, several Powers, as well as the Balkan states during the Bosnian crisis with little regard to the responsibilities and consequences of such alliances. Although its policy, at the outset, seemed broadly supportive of the Grand Vizier, Mehmed Kamil Pasha, it gradually tended to diverge from the official policies pursued by the Ottoman government.

The first initiative the CUP launched towards the end of October is typical, in that it clearly demonstrates the way in which the Committee was pursuing negotiations with several Powers at the same time with similar offers. For instance, on 27 October the well-known CUP figure, Enver Bey (later Pasha and Minister of War), approached the Austro-Hungarian Consul-General at Salonica, Alfred Ritter von Rappaport, with a suggestion that Rappaport enters into an exchange of views with himself and Rahmi Bey (another influential member of the inner circle of the CUP) with a view to easing the tension and finding a means of resolving the annexation crisis between the Dual Monarchy and the Ottoman Empire. Enver Bey conceded that the CUP could not anticipate the final views of the Porte, but stressed that the Committee could endeavour to influence the government in favour of an understanding. More important, he added, was the fact that the CUP wished to establish 'good relations' with all the Powers and, in particular, with the Dual Monarchy, which could lend its support to the Ottoman Empire in Balkan complications; he also gave Rappaport to understand that the CUP did not approve of the 'one-sided Anglophile policy' pursued by the Grand Vizier. ${ }^{45}$

Although Enver's talks with Rappaport which continued for about a month did not achieve any practical results in the way of resolving the dispute between Vienna and Constantinople, ${ }^{46}$ he and Rahmi Bey dropped hints which savoured of some kind of a military convention and closer co-operation between these two Empires with regard to Serbo-Montenegrin aspirations in the Sanjak of Novi Bazar. Placing particular emphasis upon the territorial integrity of the Ottoman Empire in the Balkans, the two CUP emissaries point- 
ed out that the Committee wanted more intimate relations with Vienna as it was mistrustful of Britain since her rapprochement with Russia in $1907 .{ }^{47}$

However, the question of whether this was an expression of sincere desire for closer relations, or even an alliance with Vienna needs to be investigated, and the evidence clearly suggests that this was simply one of the assertions which the CUP made profusely almost to all the Powers. Even while Enver Bey was negotiating with Rappaport, other representatives of the CUP were taking a markedly different line in Salonica, Paris and London. For instance, on 27 October just three days before Enver and Rappaport first met to discuss a way out of the crisis, Ahmed Riza paid a visit to the French Consulate in Salonica, and assured the Consul of the CUP's sympathy towards France. He went on to say that 'what we are expecting from the French Republic is not only moral support, but we also expect effective aid, efficient support' ${ }^{48}$ More importantly, at the end of October, the CUP had despatched a delegation led by Ahmed Riza and Dr Nâzım to the French and British capitals, and had entrusted them with the mission of 'seriously negotiating the present crisis with the ruling circles in Europe and of obtaining the utmost gains' for the Ottoman Empire. ${ }^{49}$

While Enver was dropping hints of closer relation with Vienna in his talks with Rappaport in Salonica, Ahmed Riza gave an interview to the Viennese Neue Freie Presse, on his way to Paris, in which he expressed himself with some bitterness against the Dual Monarchy. He characterized the annexation by Austria-Hungary of Bosnia and Herzegovina as a blow to the Young Turkish regime which 'had set out to lead Turkey towards a new future'; he argued that without this Austrian annexation Bulgaria could never have declared independence, and he warned that 'Turkey will never forget the Austro-Hungarian action, it leaves behind it a cloud which will long continue to overshadow the relations of the two countries. ${ }^{50}$

Ahmed Rıza was preceded to Paris by Nâzim and Lieutenant-Colonel Ahmed Cemal who promptly contacted Pichon and even the French Prime Minister, Clemenceau. They gave a memorandum to the Quai d'Orsay, proposing a substantial modification of the Capitulations and the abrogation of articles 23 and 61 of the Treaty of Berlin. ${ }^{51}$ However, Ahmed Riza chose a different tack. Arriving in Paris in early November, he gave Pichon a long 'exposé' about a combination between the Ottoman Empire and the other Balkan states, even including Bulgaria, which would be tacitly directed at Austria-Hungary. Pichon encouraged the idea..$^{52}$ This suggestion was to be pursued in London by the CUP emissaries at a meeting on 13 November with Grey and Hardinge who also supported the scheme. ${ }^{53}$ More importantly, where Enver had hinted to Rappaport at the CUP's desire for a military convention with Austria-Hungary, Ahmed Riza and Nâzım made a direct proposal for an alliance between the Ottoman Empire, France and Britain. They claimed that 
the French favoured the idea, and had promised to implement it if the British agreed..$^{54}$ Grey's refusal was tactfully expressed: 'our habit was to keep our hands free, though we made ententes and friendships. It was true that we had an alliance with Japan, but it was limited to certain distant questions in the Far East'.

Ahmed Riza and Nâzım objected that 'Turkey was the Japan of the Near East', and that the Cyprus Convention of 1878 already bound Britain to protect the Ottoman Empire against Russian aggression. Grey replied that 'the Young Turks had entire British sympathy in the good work they were doing in Turkey itself'. He added that he 'wished them well, and would help them in their internal affairs by lending them men to organise Customs, Police, and so on, if they wished them' ${ }^{55}$ To Hardinge and Grey, this meeting was a disappointing revelation: though Ahmed Riza had a 'fine face' and was a 'genuine idealist', the Young Turk leaders seemed to be 'quite impracticable . . . with scanty political ideas: the Turkish government will have a difficult job if all the Young Turks are like them'. ${ }^{56}$

However, what the CUP emissaries insisted upon in London did not turn out to be their final word. On their return to Paris at the beginning of December 1908, Ahmed Riza and the other CUP representatives contacted the AustroHungarian Ambassador, Khevenhüller, through an intermediary, Back de Sur.ny. They assured him that Austria-Hungary's negotiations with the Grand Vizier and the Ottoman government would serve no useful purpose, 'as these persons are puppets of the Committee' ('weil diese Puppen sein in der Hand des Comités'). More importantly, they further said that they would accept the annexation in return for $100,000,000$ francs $(4,000,000 \mathrm{TL})$ compensation, in addition to some bakschisch for the negotiators. ${ }^{57}$

It is impossible to be sure what calculations lay behind the CUP's apparently contradictory overtures to Austria-Hungary, on the one hand, and to Britain and France, on the other. However, the following observations may be made. Firstly, the CUP appears to have regarded the annexation crisis as an opportunity for exercises in grand policy, expressed in contradictory offer of alliances to Britain and France. Secondly, the CUP's willingness to offer its alliance indiscriminately to the Central Powers as well to the Entente Powers appears to confirm that it had no fundamental preference for either group, the obverse side of its underlying suspicion and mistrust of all the Great Powers. It is, therefore, clear that all the assumptions about the CUP's or the Young Turks' sincere inclinations towards Britain and France as the latter countries were representatives of constitutional regimes need to be taken with a pinch of salt. If anything, the CUP appears to have come to power in 1908 with possibly more fundamental anti-British and, by implication, anti-French sentiments than any other government in the Ottoman Empire in the course of the nineteenth and early twentieth centuries. 


\section{NOTES}

1. S. Deringil, 'The Ottoman Response to the Egyptian Crisis of 1881-1882', Middle Eastern Studies, Vol.24, No.1 (January 1988); H. Ünal, 'Ottoman Foreign Policy During the Bosnian Annexation Crisis, 1908-1909' (Unpublished Ph.D. thesis, University of Manchester, 1992).

2. See, for instance, E.D. Akarl, 'The Problems of External Pressures, Power Struggles and Budgetary Deficits in Ottoman Politics under Abdülhamid II (1876-1909): Origins and Solutions' (Unpublished Ph.D. thesis, Princeton, 1976); F.A.K. Yasamee, 'The Ottoman Empire and the European Great Powers, 1884-1887' (Unpublished Ph.D. thesis, University of London, School of Oriental and African Studies, 1984).

3. F. Ahmad, 'Great Britain's Relations with the Young Turks, 1908-1914', Middle Eastern Studies, Vol.2, No.4 (1966), pp.302-29; J. Heller, British Policy towards the Ottoman Empire, 1908-1914 (London, 1983); F. Ahmad, 'The Late Ottoman Empire', in M. Kent (ed.), The Great Powers and the End of the Ottoman Empire (London, 1984), pp.13-17; B. Samardziev, 'British Policy towards the Young Turk Revolution, 1908-1909 (Some Problems)', Bulgarian Historical Review (Sofia,1986), III., pp.22-42.

4. For instance, in an earlier study, for which extensive use has been made of British archive material together with Ottoman, Austrian and German published and unpublished documents, this view of Britain's attitude towards the Ottoman Empire has been challenged. It has been argued that it was not the British who alienated the Young Turks, pushing the latter into the German orbit; but perhaps the Young Turks' own policy which alienated the British, whether intentionally or unintentionally, resulting in the total isolation of the Ottoman Empire by 1911. See H. Ünal, 'British Response to the Young Turk Revolution; the First Year, 1908-1909: A Reassessment', in F.A.K. Yasamee (ed.), The Young Turks and the Young Turk Revolution of 1908 (forthcoming).

5. Most of the Young Turks' memoirs, for instance, were jotted down with a view to defending their conduct of affairs. All of them were, indeed, written after the First World War, the most famous being Talat Pasha's long interview with Aubrey Herbert that took place in 1921 in Berlin after the former Young Turk leader and ex-Grand Vizier had fled the country. During this interview, Talat Pasha maintained on several occasions that the CUP had always sought British friendship and advice; but that Britain was in no mood to offer any assistance whatsoever. See, for the interview, A. Herbert, Ben Kendim: A Record of Eastern Travel (London, 1924), pp.307-29; M. Fitzherbert, The Man Who Was the Greenmantle: A Biography of Aubrey Herbert (London, 1984), pp.232-4. See, for the subsequent memorandum on his interview with Talat Pasha, prepared by Aubrey Herbert for the attention of the British Foreign Office, Aubrey Herbert Papers (hereafter, AHP), DD/DRU,56 (Somerset Record Office, Britain). See, also, Cemal Pasha's memoirs, Memories of a Turkish Statesman, 1913-1919 (London, 1922).

6. See, for details of this split and the growth of the Young Turk opposition abroad, M.S. Hanioğlu, Bir Siyasal Örgüt Olarak Ittihat ve Terakki ve Jön Türklük, 1889-1902, I (Istanbul, 1986), pp.351-5; E.E.JR. Ramsaur, The Young Turks. Prelude to the Revolution of 1908 (Princeton, 1957), pp.66-9.

7. M.Ş. Hanioğlu, 'Jön Türklerin Siyasi Düsünceleri, 1899-1908', paper presented to the Conference on the 'Young Turks and the Young Turk Revolution' (March 1988, Manchester).

8. ' $\ldots$ The Muslims are beginning to see clearly into these manoeuvres. It is the competitors of the English in the East who are helping them to open their eyes. They tell them that England behaves with jealousy and hatred, that she is displeased and "has had enough" of the Sultan's systematic opposition to the demands relating to the affairs of certain British subjects. She lets it be known that, weary of this persistent hostility of the Ottoman government towards her, she will henceforth seize upon every opportunigy to torment her adversaries.' 'L'Angleterre et l'Orient', Mechveret Supplément Français, 1 Jan. 1906.

9. Ittihad ve Terakki Cemiyeti'nin 1906-1907 Senelerinin Muhaberat Kopyast, Atatürk Kütüphanesi, Belediye, Yazma no: 030 (Copy of the Correspondence Book of the CUP for the years of 1906-1907 - Atatürk Library - Municipality).

10. For Halil Halid Bey, see, his memoirs, Halil Halid, The Diary of a Turk (London, 1903). 
11. Ittihad ve Terakki Cemiyeti'nin 1906-1907 Senelerinin Muhaberat Kopyası.

12. Ibid.

13. 'Le Rapprochement Anglo-Russe', Mechveret Supplément Français, 1 July 1906.

14. 'Hypocrisies Européennes', Mechveret Supplément Français, 1 Aug. 1907.

15. 'Le Péril Slave', Mechveret Supplément Français, 1 March 1906.

16. Ibid.

17. The CUP sent a note to all the Powers' consulates, except the Russian one, in Monastir in May 1908 before the Young Turk revolution took place, announcing its existence, and criticizing foreign meddling in the internal affairs of the Ottoman Empire. See, for the text of the note, 'Memorandum Aux Puissances', in Heathcote (British Consul at Monastir) to Barclay (British Chargé d'Affaires at Constantinople), 2 June 1908, FO294/43. See, also, for the text, Mechveret Supplément Français, 1 July 1908.

18. See, for details of these events, Y.H. Bayur, Türk Inkllâbi Tarihi (Ankara, 1983), I/1., pp.1978.

19. ('Unwarranted and insulting summons'); 'Croisade Navale', Mechveret Supplément Français, 1 Dec. 1905.

20. Ibid.

21. 'Les Démonstrations Navales', Mechveret Supplément Français, 1 June 1906.

22. 'Une Alliance Qui s'impose', 1 July 1907; 'La Perse et l'Europe', 1 April 1907; 'Aux Patriotes Turcs et Persan', Mechveret Supplément Français, 1 Sept. 1907,

23. 'Acem-Türk Thtilafi', Șura-yı Ümmet, 13 Aug. 1907, nos.98-97.

24. Y.H. Bayur, op. cit., $\mathrm{V} / 1 .$, pp.341-51, 369.

25. See, for instance, the articles, 'Kafkasya'dan Mektup', 14 Nov. 1907 and 'Osmanlılar' (Leading article), 14/08/07, the Sura-yi Ümmet, nos: 106, 99.

26. One further aspect of CUP's anti-Europeanism was its economic nationalism. Though less frequently vented in CUP publications before the Young Turk Revolution of 1908, its underlying disgust at the capitulatory regime dictated by the Powers was boundless. See, for example, 'Imtiyazat-1 Ecnebiyye (Kapitülasyon)', the Șura-yı Ümmet, 28/08/07, no.98.

27. Ahmed Riza to King Edward VII, 17 Aug. 1908, FO371/545,28993. Ahmed Riza expressed the hope that by offering the Ottoman people sympathy and support, under these difficult circumstances, Britain and King Edward VII would acquire an inalterably favourable position all over Turkey. He added that Turkey under the new regime only aspired to work for the pasific development of the Empire and regain its rank in the European Concert.

28. Grey to Ahmed Riza (prepared and signed by Louis Mallet, Head of the Eastern Section in the Foreign Office) together with a letter of acknowledgement from King Edward VII, 20 Aug. 1908, Ahmed Rıza Evrakı/Ahmed Rıza Papers (in the care of Dr M.Ş. Hanioğlu); FO371/545,28993). Evidence in the British archives, however, seems to belie Grey's assertion about Ahmed Riza's well-known reputation. When Ahmed Rıza had written to Grey a few months before the Young Turk revolution, criticizing foreign meddling in the affairs of Macedonia, no-one in the British Foreign Office seemed to know of the Young Turk leader. His letter had not even been acknowledged: 'we do not answer letters from the Young Turk party . . . this is our rule' (Ahmed Riza to Grey, 20 March 1908, FO371/540,9807, and minutes). In 1907, the British Embassy had described Ahmed Riza as a 'very suspicious and untrustworthy character'. See, Bertie to Grey, 28 Feb. 1907, FO371/346,6840.

29. Bertie to Grey, 3 Sept. 1909, FO371/546,30702.

30. In a letter to the Kaiser, Ahmed Riza explained the CUP's stance with respect to Germany, stating that 'Seine Majestät stets ein treuer Freund des ottomanischen Volkes bleiben, und auch der türkischen Armee allerhochst sein Interesse in alle Zukunft erhalten werden' ('His Majesty remains the true friend of the Ottoman people, and his highest possible interest in the Turkish Army will be maintained in the future') (Lancken to the German Foreign Office, 15 Aug. 1908, Die Grosse Politik der europäischen Kabinette, 1871-1914 (hereafter Grosse Politik.) (Edited by J. Lepsius, A. Mendelsshon-Bartholdy and F. Thimme, Berlin, 19221927), 26/2, nos:8902 and note p. 596).

31. Bülow wrote to the German Foreign Minister that he had indicated to Ahmed Riza that 'the currently leading circles in Turkey should enjoy the full understanding and support of the Imperial German Ambassador who is reliable, proven and enlightened friend of the Turkish 
nation, the Ottoman Empire and Islam' ('dass ich Riza gesagt habe, die gegenwärtig in der Türkei massgebenden Leute würden bei dem Kaiserlichen Botschafter, der ein erprobter, bewährter und erleuchteter Freund des türkischen Volkes, des ottomanischen Reichs und des Islams sei, volles Verständnis und Unterstützung finden') (Bülow to the German Foreign Office, 3 Sept. 1908, Grosse Politik., 26/2, no:8908). Ahmed Riza's memoirs do not even mention his activities in Europe before his return to Constantinople. See his memoirs, Ahmed Rıza Bey, Meclis-i Mebusan ve Ayan Reisi Ahmed Rıza Bey'in Antlarl (Istanbul, 1988), pp.24-6.

32. Ünal, op. cit., p.73.

33. Ibid.

34. For details of tzzet Pasha's escape, see, FO371/544, 25781,26789,26792,26801.

35. FO371/548,28458.

36. Lowther to Grey, 2 Sept. 1908, FO371/559,31787.

37. Lowther to Grey, 12 Dec. 1908, FO371/560,36118, and minutes.

38. T. Vlakhov, Krizata v Bălçaro-Turskite Otnosheniya, 1895-1908 (Sofia, 1977), p.143.

39. According to some Bulgarian press reports, the Young Turks even decided to erect monuments in various parts of Macedonia in memory of fallen Bulgarian 'chetniks' (band leaders) who had fought against the previous regime. See, for instance, reports from Refik Bey (Deputy Ottoman-Imperial Commissioner at Sofia) in Bâb-1 Âli Evrak Odası, Eyâlet-i Mümtâze, Bulgaristan Evrakı (hereafter AMTZ.), 169/57. See, also, Vlakhov, op. cit., pp.147-8.

40. The Austro-Hungarian Ambassador at Constantinople, Pallavicini, believed at the initial stages of the Young Turk revolution that a Balkan League, including Bulgaria, and even friendly to Vienna, might become a reality. See, for the Austro-Hungarian documents, Pallavicini to Aehrenthal, Österreich-Ungarns Aussenpolitik von der bosnischen Krise 1908 bis zum Kriegsausbruch 1914 (eds. L. Bittner and Uebersberger) (Vienna, 1930) (hereafter OUA), I., no.34.

41. For the CUP's relations with various Greek groups prior to the Young Turk revolution of 1908, see, A.J. Panayotopoulos, 'Early Relations between the Greeks and the Young Turks', Balkan Studies, XXI (Thessaloniki, 1980), pp.89--90; M.Ş. Bleda, Imparatorluğun Çöküsü (Istanbul, 1979), pp.23-5; D. Dakin, The Greek Struggle in Macedonia, 1897-1913 (Thessaloniki, 1966), pp.377-9.

42. Dakin, The Greek Struggle, pp.378-92.

43. Ibid.

44. See, for these publications, note 3, above.

45. Rappaport to Aehrenthal, 27 Oct. 1908, PA, XII,351, Türkei Liasse XXXIX/1b (Verhandlungen anlässlich der Annexion Bosniens und der Herzegowina mit dem jungtürkischen Komité in Saloniki - hereafter, PA, XII,351, Türkei, Liasse XXXIX/1b), no.89.

46. For the details of these talks, see Ünal, op. cit., pp.185-8.

47. Rappaport to Aehrenthal, 11 Nov. 1908, PA, XII, 351, Türkei, Liasse XXXIX/1b, no. 93.

48. Séan (French Consul at Salonica) to Pichon, 27 Nov. 1908, Ministre des Affaires Etrangères (Quai d'Orsay), Paris, Nouvelle Série, Turquie, 192.

49. The evidence suggests that this initiative was launched without the Grand Vizier's foreknowledge. See, for Ottoman documents, Yıldız Tasnifi, Yıldız Esas Evrakı, Sadrazam M. Kâmil Pașa Evrakına Ek (hereafter Y. Kâmil Paşa). 'Osmanlı Ittihad ve Terakki Cemiyeti Merkez-i Umumisinden Gelen Șifre Telgrafname', 29 Oct 1908, Y. Kâmil Paşa, 86/33,3255. Paul Dumont, who has obtained Dr Nâzım's private papers regarding this mission, says that the CUP group also included Lieutenant-Colonel Ahmed Cemal, and that the delegation had been designated by the CUP as early as 5 October (P. Dumont, 'Une Délégation Jeune-Turc à Paris', Balkan Studies, 28, 1, 1987, Thessaloniki, p.304).

50. See, for the interview, Carnegie (British Ambassador at Vienna) to Grey, 8 Nov. 1908, FO371/556,39868.

51. See, the Memorandum by Pichon, 22 Oct. 1908, Nouvelle Série, Turquie, 191; Dumont, op. cit., pp.307-8.

52. Memorandum by Pichon, 14 Nov. 1908, Nouvelle Série, Turquie, 194.

53. However, Grey and Hardinge rejected Ahmed Riza's scheme to detach Eastern Rumelia from 
Bulgaria, and transform Bosnia and Herzegovina into a buffer state 'under the administration of Austria', on the grounds that these projects, if pressed ahead, would result in war with the Dual Monarchy, as well as with Bulgaria. See Grey to Lowther, 13 Nov. 1908, Pte. Grey 54. Ibid. Papers (FO800/79); Lowther Papers (FO800/193A). See also for details Ünal, pp.192-3.

55. Ibid.

56. Ibid.; Hardinge to Lowther, 17 Nov. 1908, Hardinge Papers 11 (Cambridge University Library); Grey Papers (FO800/79); Lowther Papers (FO800/193A).

57. 'Verlangt werden 100 Millionen Francs, eventuell noch ein Bakschisch für die Unterhändler' ('. . . 100 million francs would be demanded, possibly together with some more money in the form of bakhshish for the negotiator') (Khevenhüller to Aehrenthal, 3 Dec. 1908, PA, XII, Türkei, Liasse XXXIX/1b, no.62. For other cases of corruption in which people claiming to be from the inner circle of the CUP approached English businessmen in Constantinople, and asked for 'bakhshish' in return for their favour to win contracts for British merchants, see, Lowther to Grey, 31 Aug. 1908, Pte., Lowther Papers (FO800/193B); Lowther to Hardinge, 20 Dec. 1908, Pte., Lowther Papers (FO800/193B). 